\title{
The normative dimensions of new technologies
}

\author{
Lars Ursin, Per-Erling Movik \& Allen Alvarez
}

The study of the ethical, legal and social aspects (ELSA) of technological innovation has been established as a research field and a funding category to a varying degree since the seminal ELSA program of the US Human Genome Project started 25 years ago. Recently, ELSA as an acronym has been supplemented by the advent of Responsible Research Innovation (RRI) programs. For example, RRI forms a key cross-cutting issue in the EU Horizon 2020 Research and Innovation program. While the ELSA approach is meant to focus on the (downstream) consequences of innovation, the RRI is intended to focus on the (upstream) premises underpinning innovation.

The interdisciplinary integration of research in technology ethics has been and still is challenging. One challenge is the integration of different disciplinary approaches and methodologies in interdisciplinary research teams. Another is the integration of research results from other disciplines into more traditional in-house research methodologies. Many researchers encounter both of these challenges as they shift between approaches.

Empirical methodologies from social science approaches to technology ethics, such as interviews, participant observation, focus groups and conversation analysis, have become more important in research projects conducted by philosophers in technology ethics. These can be supplemented by methods that use web-based platforms, as one example. These approaches focus on how people, scientists or innovators think and act in relation to new technologies and how this relationship to technologies is influenced by social, institutional and historical changes.

The interdisciplinary integration of research teams and methodology to make these studies possible remains a challenging task. Studying the normative dimensions of technological enterprises aims to disclose the 'normative good' prospects that drive innovation processes, and to analyze the extent to which the technologies involved reinforce intended ideas of good practice. It involves normative work, unlike classical sociological or anthropological studies of value systems. Many of these approaches to technology ethics, both empirical and philosophical, are influenced by insights related to the sociological concept of double reflexivity, or similar concepts from the philosophical traditions of phenomenology or hermeneutics, and formulate methodologies in the attempt to express how this bears on our relationship to technologies. These approaches, however, tend to focus more on interpretation than on strong normative evaluation, stressing that evaluations are already present in the description of the contexts and situations studied.

The work to be pursued by philosophers in interdisciplinary research involves a normative double reflexivity, in the sense that it is an evaluative description of the normative goals embedded in innovation and technology implementation processes. The central questions related to this kind of work are: How can different methodologies contribute to identifying and interpreting the kinds of normative challenges to which technology development gives rise? What methods are appropriate to answer the normative challenges posed by emerging technologies? How do we combine empirical methods and philosophical theories in answering specific research questions related to technology development? How do we work 
with technology partners and policy makers, in committees and advisory boards, in a way that is philosophically fruitful? What kind of contributions should we aim to provide?

This special issue of Etikk $i$ praksis features papers that articulate and discuss approaches and methodologies that seek to make normative research activity and research output productive in the contexts of ongoing societal and technological decision making. The articles in various ways and to a varying degree exemplify and reflect on the methodology of the study of normativity in innovation. In the first article of this issue, Identifying the normative challenges posed by technology's 'soft' impacts, Tsjalling Swierstra highlights the normative challenges posed by what he calls technology's soft impacts, which are distinct from risks. All these challenges point to the way that the dynamics of technology emergence changes morality. The moral standards that society deploys to restrict or disturb the introduction and use of new technologies are themselves disturbed and changed by these emerging technologies. Swierstra argues that anticipating this technomoral dynamic requires examples of thick descriptions of current practices. Such thick descriptions of technomoral dynamics are presented in the papers by Thorstensen, Danielson, and Alvarez et al., also included in this special issue of Etikk i praksis.

In the second article, Why is integration so difficult? Shifting roles of ethics and three idioms for thinking about science, technology and society, Rune Nydal looks at the difficult dynamic between professional identities of science and technology researchers and social and humanities scholars. These two sectors now collaborate to make research programs and technology development more responsible. How should professional identities and understandings of research be adjusted to make this kind of collaboration work? Nydal uses three idioms for thinking about science in trying to answer this important question.

In the third article, Det monitorerede mig - Empowerment eller patologisering?, Lisbeth Kappelgaard describe the use of health care/medical apps for smart phones and other devices to aid teachers in the process of self-interpretation and identification of stressors in their work. With the help of interactionist ethnography, she explores the relation between the way these apps present information about the user and the way this information is interpreted in the teacher's self-interpretation along three axes: 1) the app as a way of being reminded of oneself, 2) the app as a way of documenting oneself, and 3) the app as a way of categorizing one's states. Kappelgaard shows how difficult it might be for the individual to get a kind of meta-perspective on the technology, which she argues might be a precondition for becoming empowered by it. This requires the user to be in dialogue with the technology, she says, and not to simply take it at face value.

In the fourth article, Patent holders on expert committees. Can there be a conflict of interest?, Erik Thorstensen examines whether there is conflict of interest in the process of offering policy advice on ownership of new technologies (patents) when the scientific experts tasked to serve on advisory committees are patent holders themselves. He looks into the case of patent holders on the Intergovernmental Panel on Climate Change (IPCC) panels or Working Groups that are tasked with writing reports when they also have secondary interests that might raise questions as to whether these interests are in conflict with their primary mandate.

In the fifth article, Surprising judgments about robot drivers: Experiments on rising expectations and blaming humans, Peter Danielson presents results from the N-Reasons experimental Internet survey platform, which is designed to enhance public participation in applied ethics and policy. In his Robot Ethics Survey, participants gave unexpected answers that revealed high expectations for autonomous machines and shifted blame from the machine to humans. Danielson argues that public participation using mixed quantitative and 
qualitative surveys can pose additional tests to develop further understanding of unexpected moral phenomena, and can generate surprising data that raise new questions for applied ethics. The results of the Robot Ethics Survey further suggest that introducing new kinds of artificial agents affects judgments involving technology in a very basic way, shifting blame to human victims and bystanders.

In the sixth article, Mixed views about radical life extension, Allen Alvarez, Lumberto Mendoza, and Peter Danielson also used the N-reasons method to explore the interrelationships between public attitudes toward radical life extension and cultural values. Their results suggest that there is more variation within cultural groups than between them, and that giving participants information about the issue of radical life extension does not seem to change participants' views. The authors suggest that opinion formation related to unfamiliar or recently introduced technology might follow patterns that are different than those of cultural value categorization. They suggest a possible link to research results from Swierstra and Rip (2007).

The open section contains the last article of this issue, The ethics of pedophilia, by Ole Martin Moen. Moen argues that being a pedophile is neither moral nor immoral. In his view, enjoying pedophilic fiction is morally acceptable, while adult-child sex and child pornography that harms children is morally unacceptable. Moen argues that the condemnation of pedophiles is unjust, and hinders pedophiles from being open about their sexuality to health professionals. This will make a great difference in making it possible to provide guidance and prevent abuse. Moen holds that non-offending pedophiles should be praised for their admirable willpower, rather than condemned.

We thank all the independent reviewers who closely read the submissions and wrote insightful suggestions to the authors. They all helped make the editorial process more interesting and incisive by raising detailed issues that are important not to miss.

\section{Teknologiutviklingens normative dimensjoner}

I dette spesialnummeret tematiserer vi studiet av de normative dimensjonene ved teknologiutviklingen. Kravene og bevisstheten om etisk refleksjon som en integrert del av teknologiutviklingsprosjekter er økende, samtidig som det ikke er klart hvordan en på å en god måte går frem for å foreta teknologietiske vurderinger. I dette nummeret har vi viet plass til artikler som drøfter og eksemplifiserer tilnærmingsmåter og metodologi for slike vurderinger. Dette forutsetter bevissthet om kontekst og de teoretiske vurderinger, prinsipper og verdier som vi tar med oss inn i dette feltet. Dette er nødvendig for å få et godt grep om hva som normativt står på spill, og hva denne normative dimensjonen er når vi søker å forstå utfordringene med forskning, teknologiutvikling og implementering.

Overordnede spørsmål i dette temanummeret er: Hva er passende metoder for å svare på normative utfordringer ny teknologi stiller oss overfor? Hvordan kombinerer vi empiriske metoder og filosofiske teorier i forsøket på å besvare spesifikke forskningsspørsmål relatert til teknologiutvikling? Hvordan arbeider vi med teknologipartnere og beslutningstakere, i komiteer og rådgivende organer, på måter som filosofisk er produktive? Hvilke bidrag bør vi sikte mot å yte?

\section{Reference}

Swierstra, T., \& Rip, A. (2007). Nano-ethics as NEST-ethics: patterns of moral argumentation about new and emerging science and technology. Nanoethics, 1(1), 3-20. 


\section{Guest editors for Etikk i praksis 1/2015}

Lars Øystein Ursin (PhD in Philosophy, NTNU) is a Senior Researcher at the Norwegian University of Science and Technology (NTNU). His current research projects are The ethical basis for parental decisions regarding medical treatment of extremely premature babies at the University's Department of Public Health and General Practice, and Eco-values as product quality attributes in manufacturing agricultural food ingredients at the Department of Philosophy and Religious Studies. Ursin's primary research interests are in political and social theory, applied ethics, and philosophy of mind.

E-mail: lars.ursin@ntnu.no

Per-Erling Movik is a PhD candidate at NTNU's Department of Philosophy and Religious Studies. His research project involves a study of the psychopharmacological enhancement of cognitive and emotional function framed as the individual's existential choice for selfrealization. The project's central issues explore how an individual can interpret her own will to use enhancements, how she can frame this choice in relation to her normal condition and any potential breakdown in that condition, and how she can conceptualize her developing character.

E-mail: per-erling.movik@ntnu.no

Allen Alvarez ( $\mathrm{PhD}$ in Philosophy, University of Bergen) is a Researcher for the project Applied Ethics: Technology and Governance of Health and Natural Resources at NTNU's Programme for Applied Ethics, Department of Philosophy and Religious Studies. He has worked on a postdoctoral project at NTNU in globalization, cultural conflicts and ethics of enhancement technologies which involved conducting online deliberative experiments and reflecting on the role of culture-based reasons in public debates about new technologies. E-mail: allen.alvarez@ntnu.no 